\title{
EFFECT OF IRRIGATION AND MULCH MATERIALS ON GROWTH AND YIELD OF WHEAT
}

\author{
S. Rummana ${ }^{1}$, A.K.M.R. Amin ${ }^{1 *}$, M.S. Islam and G. M. Faruk ${ }^{2}$ \\ ${ }^{1}$ Department of Agronomy, Sher-e-Bangla Agricultural University \\ ${ }^{2}$ Deputy Secretary, Ministry of Health and Family Welfare \\ *Corresponding author, E-mail: ruhulsau@yahoo.com
}

(Received: 14 December 2017, Accepted: 01 October 2018)

Keywords: Wheat, Irrigation, Mulch, Straw, Rice husk, Plastic sheet, Yield

\begin{abstract}
An experiment was carried out in Agronomy field of Sher-e-Bangla Agricultural University, Dhaka to find out the performance of wheat (var. BARI Gom 27) as influenced by time of irrigation and different mulch materials during 2015-2016. Four levels of irrigation viz. control, one irrigation at CRI (crown root initiation) stage, one irrigation at flowering stage and two irrigations each at CRI + flowering stage; and four different mulch materials viz. control, rice straw, rice husk and plastic sheets were considered as treatment variables. The experiment was laid out in a split- plot design with three replications, assigning irrigation to main plot and mulch materials to sub plots. Results showed that time of irrigation and different mulch materials had significant effect on plant characters, yield and yield components of wheat. Two irrigations given at CRI + flowering stage resulted with significantly higher plant height, number of spikelets spike ${ }^{-1}$, number of grains spike ${ }^{-1}, 1000$ - grain weight, grain yield, straw yield and harvest index over one irrigation and control plots. Among mulch materials, black plastic mulch resulted with significantly higher grain yield of wheat. The highest grains $\left(4.15 \mathrm{tha}^{-1}\right)$ and straw yields $\left(4.25 \mathrm{tha}^{-1}\right)$ were obtained with two irrigations at CRI and flowering stage with black plastic mulch for achieving higher productivity.
\end{abstract}

\section{Introduction}

Wheat (Triticum aestivum L.) is the second largest cereal crop next to rice in Bangladesh. During the year 2014-2015, 1347926 M. tons of wheat was produced from 436814 hectares of land with an average yield of $3.1 \mathrm{t} \mathrm{ha}^{-1}$ in the country (BBS, 2015). The months of December and January are almost dry where; July receives maximum precipitation of $12.85 \%$ (BBS, 2015). The residual soil moisture following the rainy season is abundantly available at early stage of the crop, but not usually retained in the later stage. So water is the most important limiting factor for wheat production. More than $80 \%$ of the water resources from surface runoff and groundwater have been used for irrigation. The excessive exploitation of groundwater resources from shallow and deep aquifers has caused the water table to fall and create many other environmental problems (Liu and Wei, 1989). The groundwater table is falling steadily at the rate of about $1 \mathrm{~m}$ per year and the main factors leading to this fall are the expanding wheat area which is irrigated with groundwater and the low water-use efficiency of crops (Hu et al., 2002). The availability of water for irrigated wheat (water requirement of high yielding variety normally varies from 400 and $500 \mathrm{~mm}$ ) is also gradually becoming limited. Mulching has been proved to be beneficial in conserving moisture and increasing productivity of wheat (Chakraborty et al., 2008). Mulching is an important agronomic practice to reduce moisture loss from soil surface. Mulching is a traditional practice in agriculture which acts as a barrier to evaporation, soil temperature could be raised or reduced depending on growing season and crop 
requirement, higher yield and quality, less infestation of insect and disease, prolonged growing season, higher nutritive value of the produce, improved storage ability etc. transfer of vapor or heat from the soil. Mulching is done with crop residues, polythene paper, ordinary paper, gravel, concrete etc. The most well known benefits of mulching are soil moisture and temperature regulation, suppressing weeds, improving germination and emergence of seedlings. Plastic sheets and rice husk are also effective mulch material.

However, very few studies were carried out in Bangladesh regarding the effect of irrigation and mulching in wheat. Therefore, this study is designed to understand the interactive effect of variable irrigation levels and different mulch materials on growth and productivity of wheat.

\section{Materials and Methods}

The experiment was conducted at the Agronomy field and laboratory, Sher-e-Bangla Agricultural University, Dhaka-1207 during the period from November, 2015 to March, 2016. Before sowing, wheat var. BARI Gom 27 seeds were tested for germination (over 90\%). The experiment was set up in November in a split- plot design where accommodate irrigation treatments viz .control $\left(\mathrm{I}_{0}\right)$, one irrigation at CRI stage $\left(\mathrm{I}_{1}\right)$, one irrigation at flowering stage $\left(\mathrm{I}_{2}\right)$ and two irrigations each at CRI + flowering stage $\left(\mathrm{I}_{3}\right)$ in main plot and and mulch materials (control, rice straw, rice husk, and black plastic sheets) in sub-plot. The size of each unit plot was $4.0 \mathrm{~m}$ x $2.5 \mathrm{~m}$ with row to row distance was $50 \mathrm{~cm}$. The land was fertilized with cow dung

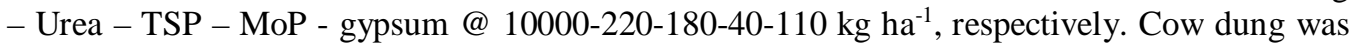
applied 10 days before final land preparation. Total amount of triple superphosphate, muriate of potash, gypsum and half of urea were applied at basal doses during final land preparation. The remaining 50\% urea was side dressed at 35 days after sowing (DAS). Flood irrigation applied with plastic pipe in individual plots as per treatment. Mulch materials were applied in the plots as per treatment after completion of germination. For mulching, upper surface of soil of respective plot (as per treatment) was covered with the mulch materials.

Data on grain yield and yield components were recorded. Grain yield was adjusted at $14 \%$ moisture content. The data was analyzed using a computer operated program STAT 10.

\section{Results and Discussion}

\section{Effect of Irrigation on plant height and yield component}

Plant height and yield components differed significantly due to different levels of irrigation (Table 1). At harvest the tallest plant $(76.02 \mathrm{~cm})$ was obtained with two irrigations at CRI + flowering stage and the shortest plant from $\mathrm{I}_{0}$ (Control). Spikelet spike ${ }^{-1}$ was influenced by different irrigation level (Table 1). The highest (45.00) number of spikelet was found with two irrigation at CRI + flowering stage. One irrigation at CRI and at flowering resulted with similar spikelet spike $^{-1}$. Lowest number of spikelets (39.31) was found with control treatment. This result was in agreement with the findings of Ali and Amin (2007).Two irrigations at CRI + flowering $\left(\mathrm{I}_{3}\right)$ reflected the highest ( 49.71) number of grains spike ${ }^{-1}$. One irrigation at flowering $\left(\mathrm{I}_{2}\right)$ and control $\left(\mathrm{I}_{0}\right)$ appeared with the lowest numbers (44.64 and 43.59, respectively) of grains spike ${ }^{-1}$. Mushtaq and Muhammad (2005) reported that the increased frequency of irrigation improved the number of grains spike $^{-1}$. Moreover, thousand grain weight was significantly influenced by different level of irrigations (Table 1). Two irrigations at CRI + flowering facilitated to produced the grains of maximum weight value $\left(45.96 \mathrm{~g}\right.$ ) followed by $\mathrm{I}_{1}$ (one irrigation at CRI) $41.51 \mathrm{~g}$ and $\mathrm{I}_{2}(40.04 \mathrm{~g}$ ) (one irrigation at flowering). The lowest thousand grain weight (38.28 g) was obtained from $\mathrm{I}_{0}$ (control) which were comparable with those of Kong et al. (2008) and Mushtaq and Muhammad (2005).

\section{Grain and Straw Yield}


Irrigation levels showed significant variation in grain yield of wheat (Table 1). The highest grain yield $\left(3.37 \mathrm{t} \mathrm{ha}^{-1}\right)$ was recorded from two irrigations at CRI and flowering of plants. Among the treatments, the control plots appeared with lowest grain yield $\left(1.72 \mathrm{t} \mathrm{ha}^{-1}\right)$. Straw yield was also affected due to irrigation treatments. Two irrigations ( $\left.\mathbf{I}_{3}\right)$ facilitated better growth of rice straw resulting the highest yield $\left(3.98 \mathrm{t} \mathrm{ha}^{-1}\right)$ compare to the other irrigation levels including control treatments (Table 2). Irrigation number and timing also have better effects on plant growth and yield of rice as revealed in this study is also supported by Chaudhary and Dahatonde (2007).

Table 1. Effect of irrigation on plant height, yield and yield attributes of wheat

\begin{tabular}{lcccccc}
\hline Treatment & $\begin{array}{c}\text { Plant height } \\
\text { at harvest } \\
(\mathrm{cm})\end{array}$ & $\begin{array}{c}\text { Spikelets } \\
\text { spike }^{-1} \\
(\text { no. })\end{array}$ & $\begin{array}{c}\text { Grain } \\
\text { spike }^{-1} \\
(\text { no. })\end{array}$ & $\begin{array}{c}\text { 1000- grain } \\
\text { weight }(\mathrm{g})\end{array}$ & $\begin{array}{c}\text { Grain } \\
\text { yield } \\
\left(\mathrm{t} \mathrm{ha}^{-1}\right)\end{array}$ & $\begin{array}{c}\text { Straw } \\
\text { yield } \\
\left(\mathrm{t} \mathrm{ha}^{-1}\right)\end{array}$ \\
\hline $\mathrm{I}_{0}$ & 63.41 & 39.31 & 43.59 & 38.28 & 1.72 & 2.26 \\
$\mathrm{I}_{1}$ & 73.22 & 43.03 & 46.91 & 41.51 & 3.07 & 3.44 \\
$\mathrm{I}_{2}$ & 67.17 & 42.64 & 44.64 & 40.04 & 2.57 & 3.11 \\
$\mathrm{I}_{3}$ & 76.02 & 45.00 & 49.71 & 45.96 & 3.73 & 3.98 \\
\hline LSD $_{(0.05)}$ & 1.04 & 1.81 & 1.45 & 0.64 & 0.02 & 0.02 \\
$\mathrm{CV}(\%)$ & 1.49 & 4.26 & 3.14 & 1.54 & 0.80 & 0.58 \\
\hline
\end{tabular}

Here,

$\mathrm{I}_{0}=$ Control

$\mathrm{I}_{2}=$ One irrigation at flowering

$\mathrm{I}_{1}=$ One irrigation at CRI

$\mathrm{I}_{3}=$ Two irrigations at $\mathrm{CRI}+$ flowering

\section{Effect of mulching on plant height and yield components}

At harvest the tallest plant $(74.20 \mathrm{~cm})$ was obtained with black plastic mulch and the shortest plant $(66.05 \mathrm{~cm})$ from $\mathrm{I}_{0}$ (control). Number of spikelet spike ${ }^{-1}$ differed significantly with different mulch materials (Table 2). Highest number of spikelet was obtained from black plastic mulch (44.76) which was statistically similar with rice straw mulch (43.80). Lowest spikelet number spike ${ }^{-1}$ was obtained from control (39.72). Highest number of grains (49.41) were obtained from $\mathrm{M}_{3}$ (black plastic sheet), followed by $\mathrm{M}_{1}$ (rice straw). Rice husk $\left(\mathrm{M}_{2}\right)$ and control $\left(\mathrm{M}_{0}\right)$ plots were recorded with statistically similar results (45.11 and 43.4, respectively) with control being the lowest. The result revealed that black plastic mulch appeared with calculated 5.33, 9.53 and $13.82 \%$ higher grains spike ${ }^{-1}$ than $\left(\mathrm{M}_{1}, \mathrm{M}_{2}\right.$ and $\mathrm{M}_{0}$ mulches, respectively. One thousand grain weight significantly differed due to different mulch materials (Table 2). Significantly the maximum 1000-grain weight (43.59 g) was obtained from $\mathrm{M}_{3}$ (black plastic sheet mulch). Followed by rice straw $\left(\mathrm{M}_{1}\right)$ mulch $(42.15 \mathrm{~g})$. No mulch treatment (control) showed the lowest weight (39.48 g).

\section{Grain and Straw Yield}

Grain yield ha ${ }^{-1}$ differed with different mulch materials (Table 2). Significantly the maximum grain yield was obtained from black plastic mulch $\left(3.34 \mathrm{t} \mathrm{ha}^{-1}\right)$ followed by rice straw $(2.94 \mathrm{t} \mathrm{ha}$ $\left.{ }^{1}\right)$ mulch. The use of black plastic sheet as a mulch might have enhanced nutrients uptake due to favorable soil moisture which ultimately increased grain yield of wheat as also supported by $\mathrm{Li}$ et al. (2004), Deng et al. (2006) and Ramakrishna et al. (2006). Straw yield differed significantly due to different mulch materials (Table 4). Highest straw yield (3.67 t ha $\left.{ }^{-1}\right)$ was obtained from $\mathrm{M}_{3}$ (black plastic sheet mulch) followed by. Rice straw mulch treatment $\left(\mathrm{M}_{1}\right)$. No mulch plot showed the lowest $\left(2.77 \mathrm{t} \mathrm{ha}^{-1}\right)$ straw yield. Deng et al., (2006) and Ramakrishna et al., (2006) also reported similar advantages of mulching in straw yield of wheat.

Table 2. Effect of mulching on plant height, yield and yield attributes of wheat 


\begin{tabular}{ccccccc}
\hline Treatment & $\begin{array}{c}\text { Plant height } \\
\text { at harvest } \\
(\mathrm{cm})\end{array}$ & $\begin{array}{c}\text { Spikelets } \\
\text { spike }^{-1} \\
(\text { no. })\end{array}$ & $\begin{array}{c}\text { Grain } \\
\text { spike }^{-1} \\
(\text { no. })\end{array}$ & $\begin{array}{c}\text { 1000-grain } \\
\text { weight }(\mathrm{g})\end{array}$ & $\begin{array}{c}\text { Grain } \\
\text { yield } \\
\left(\mathrm{t} \mathrm{ha}^{-1}\right)\end{array}$ & $\begin{array}{c}\text { Straw } \\
\text { yield } \\
\left(\mathrm{t} \mathrm{ha}^{-1}\right)\end{array}$ \\
\hline $\mathrm{M}_{0}$ & 66.05 & 39.72 & 43.41 & 39.48 & 2.27 & 2.77 \\
$\mathrm{M}_{1}$ & 71.68 & 43.80 & 46.91 & 42.15 & 2.94 & 3.36 \\
$\mathrm{M}_{2}$ & 67.88 & 41.70 & 45.11 & 40.56 & 2.54 & 2.99 \\
$\mathrm{M}_{3}$ & 74.20 & 44.76 & 49.41 & 43.59 & 3.34 & 3.67 \\
\hline LSD $(0.05)$ & 1.44 & 1.44 & 1.71 & 0.79 & 0.04 & 0.03 \\
CV $(\%)$ & 2.44 & 4.03 & 4.38 & 2.27 & 0.95 & 0.48 \\
\hline
\end{tabular}

Here,

$\mathrm{M}_{0}=$ Control

$\mathrm{M}_{2}=$ Rice husk

$$
\begin{aligned}
& M_{1}=\text { Rice straw } \\
& M_{3}=\text { Black plastic sheet }
\end{aligned}
$$

\section{Interaction effects on plant height and yield components}

Plant height was significantly influenced by interaction effect of irrigation and mulching. The maximum plant height $(80.20 \mathrm{~cm})$ was obtained with $\mathrm{I}_{3} \mathrm{M}_{3}$ which was statistically similar to $\mathrm{I}_{3} \mathrm{M}_{1}$ (two irrigations at CRI + flowering and rice straw mulch). The shortest plant $(59.47 \mathrm{~cm}$ ) was obtained from $\mathrm{I}_{0} \mathrm{M}_{0}$. Different combination of irrigation levels and mulch materials showed significant variation in the number of spikelet spike ${ }^{-1}$ (Table 3). The combination $\mathrm{I}_{3} \mathrm{M}_{3}$ appeared with the maximum number of spikelets spike ${ }^{-1}$ (47.18), followed by $\left.I_{3} M_{1}, I_{1} M_{3}\right), I_{2} M_{3}$ and $I_{1} M_{.1}$, respectively. Control treatment $\left(\mathrm{I}_{0} \mathrm{M}_{0}\right)$ showed the lowest number (37.17) of spikelets spike ${ }^{-1}$. Highest number of grains spike ${ }^{-1}$ (52.53) was obtained from $\mathrm{I}_{3} \mathrm{M}_{3}$ combination which was statistically similar to $\mathrm{I}_{3} \mathrm{M}_{1}$ (50.61)and $\mathrm{I}_{1} \mathrm{M}_{3}$ (50.90) combinations. Lowest grain spike ${ }^{-1}$ was obtained from $\mathrm{I}_{0} \mathrm{M}_{0}$ (41.27) which was statistically similar to $\mathrm{I}_{0} \mathrm{M}_{1}$ (44.53) and $\mathrm{I}_{0} \mathrm{M}_{2}$ (42.08). In the case of 1000- grain weight $\mathrm{I}_{3} \mathrm{M}_{3}$ showed with the maximum weight (47.53 g) and that was statistically similar to $\mathrm{I}_{3} \mathrm{M}_{1}(46.27), \mathrm{I}_{3} \mathrm{M}_{2}$ (46.01) and $\mathrm{I}_{1} \mathrm{M}_{1}(46.17 \mathrm{~g})$. The lowest weight of 1000 - grains $\left(37.11 \mathrm{~g}\right.$ ) were obtained from $\mathrm{I}_{0} \mathrm{M}_{0}$ (control) which was statistically similar to $\mathrm{I}_{0} \mathrm{M}_{1}(37.83 \mathrm{~g}), \mathrm{I}_{0} \mathrm{M}_{2}(38.34 \mathrm{~g}), \mathrm{I}_{1} \mathrm{M}_{2}(38.38 \mathrm{~g}), \mathrm{I}_{2} \mathrm{M}_{0}(38.17 \mathrm{~g})$ and $\mathrm{I}_{2} \mathrm{M}_{1}(38.34 \mathrm{~g})$.

\section{Yield}

Different combination of irrigation levels and mulch materials showed significant variation in grain yield $\mathrm{ha}^{-1}$ (Table 3). The $\mathrm{I}_{3} \mathrm{M}_{3}$ combination (2 irrigations at CRI + flowering and black plastic sheet) expressed with the highest grain yield $\left(4.15 \mathrm{t} \mathrm{ha}^{-1}\right)$ which was significantly different from other treatment combinations. Second highest grain yield $\left(3.98 \mathrm{t} \mathrm{ha}^{-1}\right)$ was obtained from $\mathrm{I}_{3} \mathrm{M}_{1}$ combination. These results revealed that the soil moisture was most efficiently utilized under black plastic mulch. On the other hand the lowest grain yield $(1.41 \mathrm{t}$ ha $^{-1}$ ) was obtained from $\mathrm{I}_{0} \mathrm{M}_{0}$ (control). Combined effect of irrigation and mulching showed significant effect on straw yield (Table 3). Among the combinations, the highest straw yield $\left(4.25 \mathrm{t} \mathrm{ha}^{-1}\right)$ was obtained from $\mathrm{I}_{3} \mathrm{M}_{3}$ combination. Lowest straw yield $\left(1.98 \mathrm{t} \mathrm{ha}^{-1}\right)$ was obtained from $\mathrm{I}_{0} \mathrm{M}_{0}$ (control).

Table 3. Interaction effect of irrigation and mulching on plant height, yield and yield attributes of wheat

\begin{tabular}{ccccccc}
\hline Interaction & $\begin{array}{c}\text { Plant height } \\
\text { at harvest } \\
(\mathrm{cm})\end{array}$ & $\begin{array}{c}\text { Spikelets } \\
\text { spike }^{-1} \\
(\text { no. })\end{array}$ & $\begin{array}{c}\text { Grain } \\
\text { spike } \\
(\text { no. })\end{array}$ & $\begin{array}{c}\text { 1000- grain } \\
\text { weight }(\mathrm{g})\end{array}$ & $\begin{array}{c}\text { Grain } \\
\text { yield } \\
\left(\mathrm{t} \mathrm{ha}^{-1}\right)\end{array}$ & $\begin{array}{c}\text { Straw } \\
\text { yield } \\
\left(\mathrm{t} \mathrm{ha}^{-1}\right)\end{array}$ \\
\hline $\mathrm{I}_{0} \mathrm{M}_{0}$ & 59.47 & 37.17 & 41.27 & 37.11 & 1.41 & 1.98 \\
$\mathrm{I}_{0} \mathrm{M}_{1}$ & 65.50 & 40.13 & 44.53 & 37.83 & 1.88 & 2.47 \\
$\mathrm{I}_{0} \mathrm{M}_{2}$ & 61.47 & 38.57 & 42.08 & 38.34 & 1.62 & 2.10 \\
$\mathrm{I}_{0} \mathrm{M}_{3}$ & 67.20 & 41.35 & 46.47 & 39.85 & 1.97 & 2.51 \\
$\mathrm{I}_{1} \mathrm{M}_{0}$ & 69.40 & 39.93 & 43.65 & 38.64 & 2.29 & 2.85
\end{tabular}




\begin{tabular}{ccccccc}
$\mathrm{I}_{1} \mathrm{M}_{1}$ & 75.53 & 44.50 & 47.53 & 46.17 & 3.35 & 3.59 \\
$\mathrm{I}_{1} \mathrm{M}_{2}$ & 70.40 & 42.37 & 45.55 & 38.38 & 2.74 & 3.16 \\
$\mathrm{I}_{1} \mathrm{M}_{3}$ & 77.53 & 45.32 & 50.90 & 42.87 & 3.91 & 4.14 \\
$\mathrm{I}_{2} \mathrm{M}_{0}$ & 63.27 & 39.63 & 41.38 & 38.17 & 2.03 & 2.63 \\
$\mathrm{I}_{2} \mathrm{M}_{1}$ & 68.13 & 43.87 & 44.98 & 38.34 & 2.56 & 3.18 \\
$\mathrm{I}_{2} \mathrm{M}_{2}$ & 65.40 & 41.87 & 44.45 & 39.52 & 2.36 & 2.85 \\
$\mathrm{I}_{2} \mathrm{M}_{3}$ & 71.88 & 45.18 & 47.73 & 44.12 & 3.32 & 3.77 \\
$\mathrm{I}_{3} \mathrm{M}_{0}$ & 72.07 & 42.13 & 47.33 & 44.01 & 3.35 & 3.61 \\
$\mathrm{I}_{3} \mathrm{M}_{1}$ & 77.53 & 46.68 & 50.61 & 46.27 & 3.98 & 4.20 \\
$\mathrm{I}_{3} \mathrm{M}_{2}$ & 74.27 & 44.01 & 48.35 & 46.01 & 3.44 & 3.85 \\
$\mathrm{I}_{3} \mathrm{M}_{3}$ & 80.20 & 47.18 & 52.53 & 47.53 & 4.15 & 4.25 \\
\hline $\mathrm{LSD}(0.05)$ & 2.87 & 2.88 & 3.41 & 1.58 & 0.04 & 0.03 \\
$\mathrm{CV}(\%)$ & 2.44 & 4.03 & 4.38 & 2.27 & 0.95 & 0.48 \\
\hline
\end{tabular}

Here, $\mathrm{I}_{0}=$ Control, $\mathrm{I}_{1}=$ One irrigation at CRI, $\mathrm{I}_{2}=$ One irrigation at flowering, $\mathrm{I}_{3}=$ Two irrigations at CRI + flowering, $\mathrm{M}_{0}=$ Control, $\mathrm{M}_{1}=$ Rice straw, $\mathrm{M}_{2}=$ Rice husk, $\mathrm{M}_{3}=$ Black plastic sheet .

\section{Conclusion}

Based on the results of the study it can be concluded that two irrigations at CRI and flowering stage in combination with black plastic mulch is the best for obtaining higher yield of wheat.

\section{References}

Ali, M.A. and S. Amin. 2007. Effect of irrigation frequency on yield and yield attributes of wheat cultiver 'Shatabdi'. Pak. J. Agril. Sci. 2(3): 145-147.

BBS (Bangladesh Bureau of Statistics). 2015. Statistical pocket book of Bangladesh. Bangladesh Bureau of Statistics, Statistics Division, Ministry of Planning, Government of the People's Republic of Bangladesh.

Chakraborty, D., S. Nagarajan, P. Aggarwal, V. K.Gupta, R. K. Tomar,R. N. Garg, R. N. Sahoo, A. Sarkar, U. K. Chopra, K. S. S. Sarma, and N. Kalra. 2008. Effect of mulching on soil and plant water status, and the growth and yield of wheat (Triticum aestivum L.) in a semi-arid environment. Agric. Water Manage. 95: 1323-1334.

Chaudhary, A.A. and B.N. Dahatonde. 2007. Influence of irrigation frequency, irrigation depth and antitranspirants on the growth, yield and water use efficiency of wheat. Madras Agric. J. 24(1):54-55.

Deng, X. P.,L. Shan, H. P. Zhang and N. C. Turner. 2006. Improving agricultural water use efficiency in arid and semiarid areas of China. Agric. Water Manage. 80(13): 2340. doi: 10.1016/j.agwat.2005.07.021. [Cross Ref].

Hu, C.S., X. Y. Zhang, Y. S. Chengand, D. Pei. 2002. An analysis on dynamics of water table and overdraft in the piedmont of Mt. Taihang. Syst. Sci. Compr. Stud. Agric.18 (2): 89-91.

Kong, X. X., Z.P. Yanva. and W. J. Cheng. 2008. Effect of limited irrigation on yield of winter wheat and water use efficiency. Plant Soil.284: 335-350.

Li, F.M., J. Wang, J. Z.Xu. And H. L. Xu. 2004. Productivity and soil to plastic film mulching durations for spring wheat on entisols in the semiarid Loess Plateau of China. Soil Till Res.78: 9-20.

Liu, C. and Z. Wei. 1989. Agricultural Hydrology and Water Resources in the North China Plain. Chinese Scientific Press, Beijing, pp.236. 
Mushtaq, A. and S. Muhammad. 2005. Growth and yield of wheat is influenced by different irrigation frequencies. Faisalabad. Pakistan: Directorate of Agricultural Information, Ayub Agricultural Research Institute. Pak. J. Agric. Res.43(4): 331-338.

Ramakrishna, A., H. M. Tam, S. P. Wani. and T. D. Long. 2006. Effect of mulch on soil temperature, moisture, weed infestation and yield of groundnut in northern Vietnam. Field Crops Res. 95(2-3):115-125. 